\title{
ROLA LIDERA W EFEKTYWNYM ZARZĄDZANIU ZESPOŁEM PROJEKTOWYM
}

\section{WPROWADZENIE}

Na przestrzeni ostatnich lat wzrosło znaczenie zarządzania zasobami ludzkimi w organizacji. Pracodawcy kładą większy nacisk na efektywną realizację zadań podwładnych, z kolei pracownicy oczekują wsparcia i zrozumienia ze strony lidera zespołu. Rola manadżera grupy jest trudna i wymaga dobrej organizacji pracy własnej i cudzej, odpowiedzialności, umiejętności działania pod presją czasu, zaufania itp. O sukcesie zespołu decyduje efektywność lidera oraz indywidualna praca każdej osoby w grupie, które tworzą złożoną całość. Wzrosło także zapotrzebowanie na małe zespoły projektowe. Zespół osiąga większą efektywność w małej grupie. W zespole projektowym często mamy do czynienia z sytuacją, w jakiej spotykają się osoby, które wcześniej ze sobą bezpośrednio nie współpracowali. Dlatego niezwykle istotne staje się zintegrowanie zespołu i budowanie skutecznej komunikacji. Rolą lidera jest tworzenie zespołu, w którym każdy pracownik potrafi odpowiednio komunikować się ze wszystkimi w grupie. Zespół ma poczucie jedności, odpowiedzialności i jest nastawiony na rozwój i sukces. Skład zespołu w trakcie trwania projektu może podlegać zmianom. Czas trwania projektu jest zróżnicowany. Zazwyczaj projekt realizowany jest od kilku miesięcy do maksymalnie kilku lat. Lider może powoływać pracowników na zlecenie, tylko na czas wykonania określonego zadania. Jest to zdecydowanie mniej kosztowne, niż w przypadku zatrudnienia pracownika na czas trwania projektu. W procesie selekcji i rekrutacji lider wybiera osoby, dysponujące oprócz umiejętności specjalistycznych dobrze rozwiniętymi zdolnościami komunikacyjnymi. Zmniejsza to koszty ewentualnych szkoleń.

Lider definiowany jest jako osoba zarządzająca zespołem projektowym. Jest powołany do tej roli na czas trwania projektu. Po rozwiązaniu zespołu lider dalej może

\footnotetext{
* Studentka, członkini Studenckiego Koła Naukowego „HRM”, Uniwersytet Łódzki.
} 
pozostać na swoim stanowisku, pod warunkiem, że zostanie ogłoszony nowy projekt pod jego bezpośrednim kierownictwem. Występuje relacja nadrzędności lidera nad podrzędną grupą projektową. Zespół wykonuje polecenia lidera. Przywództwo lidera wiąże się z procesem wywierania wpływu na ludzi w celu osiągnięcia założonych rezultatów. Celem pracy jest ukazanie roli lidera, który w efektywny sposób zarządza zespołem. Dobry przywódca charakteryzuje się określonymi cechami. Przede wszystkim nieustannie się dokształca, wzbogaca poziom zdobytej wiedzy, uzupełnia ją lub nabywa nowe umiejętności. Po za tym wysyła pozytywną energię swoim pracownikom. Optymistycznie podchodzi do realizowanych zadań i systematycznie je wykonuje. Zawsze z życzliwością i szacunkiem odnosi się do zespołu. Skuteczny przywódca wierzy w swoich podwładnych. Docenia ich pracę i daje temu wyraz, np. w słowach lub w nagradzaniu ich za wykonaną pracę. Kierownik skutecznie zarządzający zespołem jest synergiczny, tj. grupa, która tworzy całość jest dla niego ważniejsza niż suma indywidualnych pracowników. Decyzje podejmowane są z myślą o wszystkich, a nie tylko pojedynczych osobach ${ }^{1}$.

Słowo „lider” może być także używany zamiennie z pokrewnymi pojęciami, jak "menadżer” czy „kierownik”. Terminy te niosą w sobie osobną definicję, jednak odnoszą się także to przyjętego znaczenia pojęcia „lider”. Praca została osadzona na podstawie badań brytyjskich specjalistów z dziedziny z zarządzania zespołami ludzkimi, polskich teoretyków i praktyków, którzy zajmują się stricte budowaniem zespołu projektowego oraz amerykańskich psychologów klinicznych. Niniejszy artykuł został ukierunkowany na sylwetkę lidera, poszukując przede wszystkim odpowiedzi na pytania: jakimi umiejętnościami; cechami powinien charakteryzować się efektywny lider? Jak zmotywować zespół do pracy? W jaki sposób zbudować skuteczną komunikację?

\section{DEFINICJA PROJEKTU, ZARZĄDZANIA PROJEKTAMI ORAZ ZESPOŁU PROJEKTOWEGO}

Przedsiębiorcy działają w warunkach ograniczonej niepewności, niedostatecznej wiedzy i informacji. Jednym z narzędzi wpływających na niepewność jest zarządzanie projektami.

K. Frączkowski definiuje projekt jako przedsięwzięcie złożone, na które składa się zbiór czynności, realizowanych przez grupę ludzi w wyznaczonych ramach czasowych, po określeniu celów, budżetu oraz rozdzieleniu zadań2.

Zarządzanie projektami - to zespół działań, polegających na realizacji założonego planu projektowego przy wykorzystywaniu kapitału ludzkiego (całokształt nabytej

1 R. Stephen Covey, Zasady skutecznego przywództwa, Dom Wydawniczy REBIS, Poznań 2004, s. 29-33.

2 K. Frączkowski, Zarządzanie projektem informatycznym, Oficyna Wydawnicza Politechniki Wrocławskiej, Wrocław 2003, s. 11. 
wiedzy, kompetencji i zdolności pracowników) do wykonywania wytyczonych zadań w projekcie. Jest jednym z elementów zarządzania firmą.

Zarządzanie projektami jest ściśle skorelowane z zarządzaniem zasobami ludzkimi w organizacji. Istotą zarządzania projektem jest gospodarowanie zespołem projektowym, tj. efektywne kierowanie współpracownikami w celu osiągnięcia zamierzonych zadań. To kształtowanie postaw i zachowań3 ${ }^{3}$

Zespół projektowy - to jednostka logistyczna firmy desygnowana do wykonywania zadań projektowych pod kierownictwem lidera zespołu. Zazwyczaj obejmuje maksymalnie 20 pracowników. Zespół projektowy obrazują następujące właściwości:

- działanie w określonych ramach czasowych,

- wdrożenie jednostkowego programu lub realizacja projektu częściowego, podzbioru lub segmentu,

- operowanie zadaniami na podstawie regulaminu przedsiębiorstwa, który powinien obejmować cele, kompetencje, stanowisko pracowników itp. ${ }^{4}$

\section{FAZY PROJEKTU}

Zarządzanie projektami należy odróżnić od zarządzania ciągłego firmą. W przypadku gospodarowania stałego pojawiają się zazwyczaj trudności rutynowe. Nieustanny proces zarządzania firmą niesie za sobą ryzyko znużenia, braku kreatywności i innowacyjnych działań. Jest to zrozumiałe wobec długiego czasu kierowania firmą, która podlega prawom rynkowym oraz jest uzależniona od norm prawnych, ustaw, które wprowadzają różnorodne zmiany. To może generować problemy. Inaczej sytuacja przedstawia się w zarządzaniu projektami. Tutaj częstokroć występują treści o charakterze twórczym, nieszablonowym, oryginalnym. Warto wspomnieć o roli zarządzania zasobami ludzkimi w gospodarowaniu projektem.

W zarządzaniu projektami zdecydowanie częściej niż w kierowaniu długotrwałym pracodawca sięga do specyficznych i unikatowych zbiorów. Korzysta głównie z zasobów ludzkich (kapitał ludzki, na który składają się osoby o różnych preferencjach, kompetencjach, umiejętnościach), ale także zasobów materialnych i niematerialnych (informacje na dany temat). Do tego dochodzi niejednokrotnie zmienność zadań w czasie i przestrzeni. Przedstawione zmienne częstokroć wywierają destrukcyjny wpływ na grupę projektową, rodzą napięcia, które mogą z kolei generować konflikty. Stanowią prawdziwą próbę sił lidera i jego zespołu, wymagają dużej odporności psychicznej na stres i umiejętności działania pod presją czasu ${ }^{5}$.

\footnotetext{
3 www.zarzadzanieprojekt.pl [dostęp: 1.05.2015].

4 www.mfiles.pl/pl/index.php/Zesp\%C3\%B3\%C5\%82_projektowy [dostęp: 1.05.2015].

5 P. Bohdziewicz, Efektywność gospodarowania kapitałem Iudzkim, Wydawnictwo Uniwersytetu Łódzkiego, Łódź 2011, s. 406-407.
} 
Zarządzanie projektami posiada hierarchiczną strukturę, w której podstawowe znaczenie odgrywają fazy projektu. Wyróżniamy następujące fazy projektu: faza przygotowawcza, wykonawcza oraz podsumowująca.

Faza przygotowawcza rozpoczyna proces organizowania całego projektu. Podstawowym działaniem w tym stadium jest powołanie lidera zespołu, który będzie sprawował nadzór i kontrolę nad realizacją poszczególnych zadań pracowników. Wynikiem tego etapu jest dokument wdrażający projekt. Pozwala osiągnąć założone cele zgodnie z wymaganiami klienta. Powinien zawierać przede wszystkim inicjację przedsięwzięcia oraz powołanie zespołu projektowego, w tym skład grupy oraz określenie i rozdzielenie zadań. Następnie ważne jest sprecyzowanie celów krótko- i długoterminowych. Cel powinien być konkretny, realny, mierzalny, atrakcyjny, umieszczony w czasie. W dokumencie wdrażającym projekt przedstawia się także identyfikację zysków i kosztów oraz czynniki ryzyka, które mogą pojawić się na każdym etapie projektu. Efektywny lider potrafi pokierować grupą w taki sposób, że w razie ewentualnych przeszkód zespół nie popada w gwałtowny kryzys. W fazie inicjującej przedsięwzięcie określa się także plan budżetu, przewidywany czas realizacji projektu, porządek zadań, obszar działania oraz informacje niezbędne do rozpoczęcia projektu6.

Faza realizacji stanowi kluczowy etap realizacji zadań projektowych. Polega na urzeczywistnianiu zadań, w którym decydujące znaczenie odgrywa lider zespołu. To właśnie manadżer motywuje pracowników do pracy, pełni funkcję przywódcy. Następuje proces interakcji na linii kierownik - współpracownicy. Zespół wykonuje zadania pod czujnym okiem lidera zespołu. Każda jednostka w zespole jest odpowiedzialna za swoją pracę i za sukces projektu. Jakiekolwiek potknięcia i skrajne zachowania niedojrzałości i nieodpowiedzialności rzutują na zespół i efekty końcowe. Zespół wymaga zjednoczonego składu zespołowego, by osiągnąć cele założone w planie projektowym. Tutaj pracownicy korzystają ze swojego kapitału, tj. nabytej wiedzy, umiejętności, kwalifikacji itp. Lider akcentuje potrzebę na kreatywne i innowacyjne rozwiązania. Wymaga od grupy determinacji i aktywnej pracy.

Na tym etapie działania zespół powinien wykazywać się dojrzałością, lider stworzył dogodne warunki do osiągania celów, odpowiedni klimat i atmosferę w zespole.

Natomiast faza podsumowująca jest to ostatni etap realizacji projektu. Obejmuje ocenę okresową i końcową całego projektu, zestawienie efektów z założonym planem projektowym, bilans zysków i strat, zakończenie projektu, rozwiązanie zespołu. Lider podsumowuje projekt i sporządza raport końcowy. Zakończenie projektu jest sprawozdaniem pracy całego zespołu, gdzie dokonuje się faktycznej i rzetelnej oceny wyników, ich weryfikacji, odwołując się do planu przygotowującego projekt. Rola lidera polega tutaj też na udzielaniu słusznych pochwał, wracaniu do momentów kryzysowych, wyciąganiu wniosków na przyszłość. Doświadczenie zespołu tworzy swoistą i niepowtarzalną bazę, z której zarówno lider, jak i współpracownicy będą mogli korzystać w przyszłości. Zakończenie prac jest też momentem trudnym, polega na

${ }^{6}$ www.mfiles.pl/pl/index.php/Inicjowanie_Projektu [dostęp: 1.05.2015]. 
rozwiązaniu zespołu. Lider ma tego świadomość i nie może być mowy o sentymentalizmie. Będzie nowy projekt, nowe wyzwania i osoby, które efektywnie wykonywały swoje zadania mogą liczyć na ponowne zaangażowanie. Na zakończenie, zgodnie z zasadami savoir vivre, lider dziękuję kolegom za współpracę ${ }^{7}$.

\section{ZADANIA I KOMPETENCJE LIDERA ZESPOŁU}

Efektywność zarządzania projektami zależy w dużej mierze od kompetencji i umiejętności menadżera zespołu. Grupa potrzebuje silnej i ugruntowanej pozycji lidera. Jego praca związana jest z pełnieniem określonych funkcji kierowniczych. Jest to projektowanie, koordynowanie, nadzór i weryfikacja zespołu projektowego.

Biorąc pod uwagę omawiany problem roli lidera, menadżer zarządza kapitałem ludzkim, wykonując szereg powiązanych ze sobą zadań. Przede wszystkim tworzy zespół projektowy. Spośród dostępnej bazy pracowników dokonuje selekcji i wybiera jego zdaniem najlepszych. Następnie lider organizuje pracę podwładnych, przydzielając im określone zadania. Wybiera kreatora, czyli najbardziej kreatywną i innowacyjną osobę w zespole, która wzbogaca projekt cennymi uwagami. Aby zespół efektywnie pracował, lider motywuje grupę do działania, np. poprzez system nagród i kar. W przypadku dobrze wykonanego zadania nagrodą może być premia okresowa. Natomiast w przeciwnym razie kierownik może wymierzyć pracownikowi karę np. w postaci dodatkowych godzin w pracy. Skuteczny lider posiada dobrze rozwiniętą zdolność komunikowania. W małych zespołach projektowych efektywna komunikacja wymaga zaakcentowania niezbędnych czynników. Jednym z nich jest racjonalizm, czyli innymi słowy - zdrowy rozsądek przy dostarczeniu informacji. Komunikat powinien być prosty, jasny, czytelny. Błędne jest przekazanie informacji bez oczekiwania komunikatu zwrotnego. Skuteczna komunikacja wymaga potwierdzenia treści komunikatu. Istotne znaczenie odgrywa także forma przekazania treści. Informacja powinna być przekazywana w formie ustnej, aby lider miał kontakt z pracownikiem. Warto też zwrócić uwagę na zachowanie adresata przy przekazaniu informacji. Jego ton głosu winien być zdecydowany, ale i spokojny. Nadawca utrzymuje kontakt wzrokowy z odbiorcą i przyjmuje postawę otwartości. Warto też zwrócić uwagę na interakcję na linii nadawca-adresat, na zaznaczenie wspólnych związków między liderem, a członkiem zespołu. Otwarta i swobodna komunikacja wspomaga procesy twórczego myślenia i buduje zaufanie, więź i klimat w zespole. Z kolei nieefektywna, wadliwa komunikacja kształtuje niewłaściwe wzorce zachowania pracowników, hamuje kreatywność i efektywną pracę. Grupa jest słabo zmotywowana do działania i w związku z tym nie osiąga zamierzonych wyników. Niezwykle ważne są szkolenia

7 B. Kożusznik, Kierowanie zespołem pracowniczym, Polskie Wydawnictwo Ekonomiczne, Warszawa 2005, s. 23. 
lidera i pracowników w zakresie efektywnej komunikacji. Usprawnią one procesy uczenia się i podnoszenia poziomu komunikacji w grupie. Zespół tworzy kanały komunikacyjne. Jeśli mamy cztery osoby w grupie, wtedy występuje osiem ewentualnych kanałów informacyjnych. Powyższą zależność przedstawia rysunek 1.

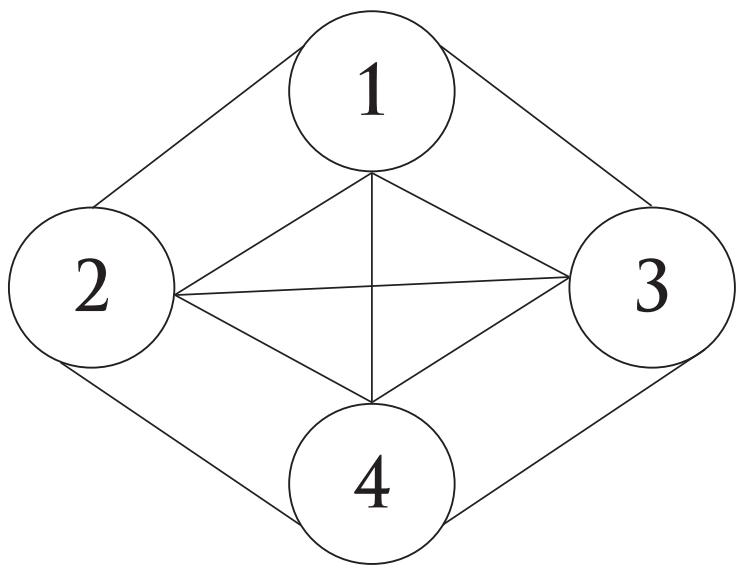

Rysunek 1. Możliwe kanały informacyjne w zespole 4-osobowym

ŹRóDŁo: oprac. własne

Efektywny lider zarządza komunikacją w sposób racjonalny i przemyślany. Aby było to możliwe, muszą łącznie wystąpić niezbędne czynniki. Jest to integracja i wzajemne zaufanie zespołu oraz właściwa identyfikacja potrzeb komunikacyjnych każdej osoby w zespole. Wobec powyższego lider poszukuje odpowiedzi na pytania: Kto potrzebuje informacji? W jaki sposób i w jakiej formie dostarczyć wiadomość? Czego oczekuję w wiadomości zwrotnej? Kiedy i w jakiej kolejności przedstawić wiadomość? Itp. Pomocne w tym zakresie będzie opracowanie list pracowników, wybór osoby odpowiedzialnej za przechowywanie informacji oraz opracowanie przez lidera instrukcji planu komunikacyjnego.

Kolejnym zadaniem lidera jest integracja zespołu. Budowanie więzi i ducha zespołu odbywa się najczęściej na wyjazdach integracyjnych, wspólnym spędzaniu wolnego czasu. Spotkania te pozwalają nabrać dystansu do realizowanego przedsięwzięcia, uwalniają pracownika od stresu i pomagają zapomnieć o ewentualnych problemach, lękach. Efektywny lider, mając na uwadze dobro zespołu i projektu, nie dopuszcza do generowania konfliktów w grupie. W przypadku nieporozumień lider od razu dociera do ogniska problemu i likwiduje powstałe nieporozumienia. Jeśli jednak w zespole znajduje się osoba, która destrukcyjnie działa na współpracowników, a rozmowy nie przynoszą żadnych rezultatów, wtedy liderowi nie pozostaje nic innego, jak wydalenie osoby z zespołu. Kolejnym i niewątpliwie ważnym zadaniem lidera jest tworzenie atmosfery wzajemnego szacunku i zrozumienia. Klimat organi- 
zacyjny stanowi jeden z najważniejszych motywatorów do efektywnej pracy. Wykonując swoje zadania, lider, jako osoba, która kieruje zespołem, wspiera pracowników swoją wiedzą, umiejętnościami i doświadczeniem. W przypadku osób, które wykazują ponadprzeciętne zdolności lider chętnie korzysta z ich talentów i wykorzystuje je do podnoszenia efektywności zespołu ${ }^{8}$.

Wobec powyższych zadań nasuwa się pytanie, jakimi umiejętnościami powinien charakteryzować się efektywny lider.

Cechy projektu i realizacja zadań właściwych wytyczają profil kompetencyjny lidera. Obejmuje on umiejętności przedstawione w tabeli 1.

Tabela 1. Profil kompetencyjny lidera

\begin{tabular}{lll}
\hline Umiejętności specjalistyczne & \multicolumn{1}{c}{ Umiejętności innowacyjne } & Umiejętności interpersonalne \\
\hline Szczególnie istotne w przy- & Odgrywają największą rolę & Dysponują nimi wszyscy \\
padku projektów nowator- & w projektach złożonych, & liderzy, powinny być tym \\
skich, niekonwencjonalnych. & wymagających dużych & wyższe, im wzrasta trudność \\
Najważniejsze z nich to: & nakładów czasu, kosztów & projektu. \\
- wiedza, & i zasobów ludzkich. & Najważniejsze z nich to: \\
- zdobyte doświadczenie, & Należą do nich: & - rozwiązywanie konfliktów, \\
- zdobyte kwalifikacje, & - kreatywność, & - budowanie relacji z ludźmi \\
np. certyfikowane umiejęt- & - zdolność do twórczego & i delegowanie uprawnień, \\
ności językowe, & i analitycznego myślenia, & - umiejętność aktywnego \\
- umiejętność zarządzania & - zdolność do wykorzy- & słuchania, empatia, \\
budżetem. & stywania nowoczesnych & - tworzenie klimatu organi- \\
& technologii, & zacji, \\
& - umiejętność szybkiego & - wywieranie wpływu na \\
& uczenia się, & ludzi, \\
& - umiejętność szybkiego & - dysponowanie informacją \\
& czytania. & w formie werbalnej i nie- \\
& & werbalnej. \\
\hline
\end{tabular}

ŹRÓDŁO: oprac. własne.

Kompetencje lidera w istotny sposób wpływają na powodzenie projektu. Niskie kompetencje kierownika zwiększają ryzyko niepowodzenia.

Kierowanie zespołem wymaga specyficznej grupy cech, jakie powinien posiadać lider. Skuteczny lider potrafi wykorzystywać zdobytą wiedzę i doświadczenie już na samym początku budowania zespołu, tj. podczas selekcji i rekrutacji kandydatów do zespołu. Nie każdy pracownik wykazuje predyspozycje przywódcze. Przywództwo wiąże się z charyzmą, tj. szczególnymi cechami, którymi dysponuje jednostka, wywierając wpływ na grupę. Lider posiada autorytet, grupa go słucha i wykonuje jego polecenia. Skuteczny lider potrafi bez większych problemów oszacować sytuację

8 R. Winkler, Przywództwo i komunikacja w zespole projektowym, „Zeszyty Naukowe Uniwersytetu Szczecińskiego" 2013, s. 478-480. 
i zidentyfikować problem, np. konflikt w zespole. Jest to niezwykle ważne. Likwidowanie na bieżąco nieporozumień usprawnia procesy komunikacyjne i nie zaburza działań grupy. Sytuacje konfliktowe, ewentualne kryzysy wymagają zachowania spokoju i opanowania ze strony lidera. Kolejną cechą lidera jest zaufanie i akceptacja ze strony podwładnych. Lider rozumie, że każdy ma prawo do gorszego dnia w pracy i grupa ma świadomość, że może na niego liczyć w trudnych sytuacjach. Efektywny lider jest odpowiedzialny za swoje czyny i słowa. Cechuje go optymizm i wiara w osiągnięcie sukcesu. Wzbudza tym samym zapał i motywację u podwładnych. Lider wobec swojego zespołu ma naturalną ufność i tym samym hamuje potrzebę dominacji i władzy. Grupa osiąga lepsze rezultaty i jest zdeterminowana do działania. Lider powinien być zdyscyplinowany w pracy. Systematycznie realizować zamierzone cele projektowe. Dobry lideruje wykazuje też tolerancję na odmienne poglądy członków zespołu. Szanuje i liczy się ze zdaniem każdego ze współpracowników. Reprezentuje dojrzałość umysłową i emocjonalną ${ }^{9}$.

Cechy te zostały opracowane na podstawie badań Mereditha Belbina, brytyjskiego naukowca w dziedzinie zarządzania zespołami. Wspólnie z grupą badawczą przeanalizował wyniki 75 firm. Ich metoda polegała na podzieleniu organizacji na 3 grupy na podstawie rezultatów finansowych (dobre, średnie i złe) oraz interpretacji rezultatów badań psychometrycznych osób sprawujących funkcje prezesa firmy. Na tej podstawie badań naukowcy opracowali powyższą listę cech efektywnego lidera firmy.

Z raportów badaczy wynika, że dobry prezes nie wyróżniał się specjalnie na tle pozostałych pracowników. Skutecznym liderem czyniła go umiejętność stworzenia atmosfery wzajemnego szacunku i zrozumienia. Swoją rolę szczególnie uwidocznił w najważniejszych momentach projektu. Był wtedy prawdziwym przywódcą. Dobrze kontrolował pracę zespołu, a w chwilach kryzysowych nie wpadał w panikę, tylko sukcesywnie wychodził z opresji. Efektywny lider nigdy nie dopuścił do chaosu i anarchii na spotkaniach. W sytuacjach konfliktowych zawsze był w stanie zaprowadzić ład i porządek ${ }^{10}$. Analizując rezultaty badania, naukowcy przedstawili także inne wnioski. Zanim przejdziemy do wyników, postawmy sobie następujące pytanie: Czy lider o bardzo wysokim ilorazie inteligencji ma większą szansę na sukces niż jego mniej inteligentni koledzy na kierowniczych stanowiskach? Odpowiedź brzmi: nie.

Badania Belbina pokazują, że Ci prezesi wcale nie osiągali lepszych wyników od liderów o średnim, bądź słabym poziomie intelektualnym. Najczęściej osiągali złe wyniki, często przeciętne, a już najrzadziej dochodzili do dobrych rezultatów. Najbardziej inteligentni liderzy poddani badaniom wykazywali najgorsze predyspozycje. Nie byli w stanie sprostać wyzwaniom, jakie stoją przed prezesem. W trudnych etapach projektu nie potrafili efektywnie zarządzać zespołem, gubili się w natłoku zadań i często wycofywali się z ogniska problemu. Ich sprawne rozumy przewyższały innych, jednak z tego powodu niejednokrotnie zwiększali dystans wobec grupy i pro-

9 M. Belbin, Zespoły zarządzające. Sekrety ich sukcesów i porażek, Oficyna a Wolters Kluwer business, Kraków 2009, s. 61-62.

10 M. Belbin, Zespoły zarządzające..., s. 64. 
wadziło to do jeszcze większej zapaści między kierownikiem a zespołem. Potrafili błyskawicznie dostrzec wady u swoich podwładnych, ale ich rady były zbyt zagmatwane i emfatyczne, by inni mogli je pojąć i zastosować. Deprymowali zespół swoją dominacją, traktując grupę jako instrument realizacji własnych interesów, kosztem poszczególnych jej członków. Takie działanie skutkowało absolutnym brakiem komunikacji. Członkowie grupy często nie występowali ze swoimi uwagami, propozycjami zmian ważnych lub mniej istotnych kwestii i część zadań uległa załamaniu lub efekty pracy były znikome.

Jak pokazały badania, dobry przywódca charakteryzował się średnim poziomem intelektualnym. Ponieważ miał zbliżony iloraz inteligencji, co pozostali członkowie grupy, komunikacja w zespole przebiegała bez większych zakłóceń. Grupa mogła liczyć na zrozumienie ze strony prezesa o dość dobrej sprawności umysłowej, a nie zdecydowanie wyższej. Lider dostrzegał talenty współpracowników i chętnie przyjmował sugestie podwładnych, którzy wykazywali wyższy od niego iloraz inteligencji. Traktował to jako zaletę, a nie wadę, którą warto zastosować w pracy zespołowej.

Natomiast prezesi o niższym ilorazie inteligencji nie potrafili zrozumieć poszczególnych członków zespołu, kompletnie nie radzili sobie w sytuacjach konfliktowych. Nie rozumieli wszystkich omawianych pojęć, nie byli w stanie opracować celów krótko i długookresowych. Nawet jeśli posiadali autorytet, to nie potrafili go wykorzystać, ani wywierać wpływ na działania grupy. Zespół nie był dobrze kontrolowany i w związku z tym w jego jądrze toczyły się narastające walki i konflikty.

Podsumowując, zbyt duże różnice $w$ ilorazie inteligencji między liderem a zespołem sprawiają, że projekt ma znacznie mniejsze szanse na powodzenie. Idealny lider to taki, który reprezentuje podobny poziom intelektualny, co jego podwładni. Idealny lider jest z pozoru podobny do szeregowych pracowników, członków zespołu, a jednak wykazuje nieprzeciętne rezultaty. Charakteryzuje się pospolitymi cechami w niestandardowej kompozycji. W praktyce trudno jest wybrać na stanowisko lidera osoby z takimi umiejętnościami, ponieważ na pierwszy rzut oka wydają się one zupełnie przeciętne ${ }^{11}$.

\section{STYLE KIEROWANIA ZESPOŁEM}

Lider zespołu reprezentuje konkretny typ zarządzania. Styl kierowania definiuje się jako sposób wpływania kierownika na zespół. Z badań pracowników Hay Group wynika, że o efektywności zespołu decyduje wykorzystanie przez lidera następujących stylów:

- dyspozycyjnego (nakaz, polecenie),

- nowatorskiego (pobudzanie do twórczego i kreatywnego myślenia),

- afiliacyjnego (podtrzymywanie więzi i współpracy),

11 Ibidem, s. 63-66. 
- przynależnościowego (współodpowiedzialność, zaufanie, poczucie więzi z zespołem),

- kierowniczego (zarządzanie zespołem),

- wspierającego (pomoc techniczna, merytoryczna, szkoleniowa i empatyczna).

Style te powinny być mądrze wykorzystywane i dostosowane do aktualnej sytuacji, np. styl wspierający jest potrzebny pracownikowi w sytuacji, gdy nie radzi sobie z emocjami, ma problemy osobiste itp. W praktyce elastyczność stosowania stylów jest ograniczona. Wynika to z braku czasu i różnych cech osobowościowych lidera. Każdy człowiek jest inny i nie da się stworzyć lidera, który będzie na bieżąco wykorzystywał wszystkie powyższe metody kierowania zespołem.

W literaturze przedmiotu spotykamy różne klasyfikacje stylów kierowania zespołem. Ciekawą koncepcję przedstawił J.A.C. Brown - szkocki psycholog kliniczny. Opracował on 3 style zarządzania: autorytarny, demokratyczny oraz nieingerujący.

Lider reprezentujący styl autorytarny aprobuje wydawanie poleceń podwładnym. Przydziela zadania pracownikom bez uprzedniej konsultacji. Surowo ocenia pracowników z realizowanych zadań. Nie nagradza ich ani nie motywuje do efektywnej pracy. Nie ma zaufania do grupy, jest podejrzliwy, nietolerancyjny, w ogóle nie liczy się ze zdaniem innych. Jego polecenie jest traktowane w kategoriach rozkazu i musi być wykonane. Często rozlicza podwładnych z wykonanej pracy, i traktuje ich stricte przedmiotowo. Liderzy autokraci dzielą się na: rygorystycznych, miłych i niezdarnych.

Lider demokrata reprezentuje odmienny styl zarządzania. Pracownicy są traktowani podmiotowo. Kierownik, przydzielając zadania, dostosowuje je do kompetencji poszczególnych członków zespołu. Szanuje zdanie zespołu, ma do niego pełne zaufanie. Wykorzystuje talenty w zespole, uczestniczy w pracach grupy. Stara się stworzyć odpowiednie wyposażenie miejsca pracy, miłą atmosferę, wysoki poziom komunikacji. Liderzy w tym modelu pełnią rolę: mentora i psychologa.

Natomiast kierownik nieingerujący pełni pośrednią rolę w zarządzaniu zespołem. Przede wszystkim nie uczestniczy bezpośrednio w pracach grupy. Aktywnie kieruje zespołem jedynie wobec osób znajdujących się wyżej w hierarchii, np. prezesa firmy. Wtedy chętnie występuje jako przedstawiciel zespołu. Po za tym zarządza grupą w minimalnym zakresie. Praktycznie nie ingeruję w pracę podwładnych, nie konsultuje z nimi realizacji zadań, jedynie rozdziela zadania i czeka na efekt końcowy.

Odmienną koncepcję stylów kierowania przedstawił R. Likert, amerykański badacz społeczny. Wyróżnił cztery modele zarządzania zespołem.

Pierwszy styl, eksploatacyjno-autorytarnym cechuje wyłączność podejmowania wszystkich decyzji przez lidera zespołu, dotyczących zarówno realizacji zadań, jak i samych podwładnych. Lider skrupulatnie ocenia działania pracowników, wymierzając surowe kary, nawet za niewielkie uchybienia. Ma przeświadczenie o niechęci pracowników do wykonywanych zadań i w związku z tym wykazuje całkowitą nieufność względem podwładnych. To działa w obie strony. Pracownicy również nie ufają przełożonemu. 
Drugi styl, protekcjonalno-autorytarny charakteryzuje także indywidualne podejmowanie wszystkich decyzji przez lidera. Jednak podlega to pewnym ograniczeniom. Kierownik dopuszcza pewną swobodę w realizacji poszczególnych zadań podwładnych, ale tylko w obszarach przez niego wyznaczonych. Lider w tym modelu stara się zmotywować pracowników do efektywnej pracy. Stosuje system nagród i kar.

W modelu trzecim, konsultacyjnym lider sam określa główne cele, ale sposoby ich realizacji definiuje z pracownikami. Podwładni mają dużą niezależność w wykonywaniu przydzielonym im zadań. Mniejsze cele pracownicy wyznaczają samodzielnie. W tym modelu kierownik również motywuje podwładnych do bardziej wydajnej pracy, odwołując się głownie do bodźców pozytywnych, zazwyczaj nagród.

Ostatni styl, uczestniczący, cechuje się dużą autonomią pracowników w wyznaczaniu celów i ich realizacji. Lider współpracuje z podwładnymi, uzgadniając z nimi większość decyzji. Motywuje grupę do wydajnej pracy za pomocą dóbr materialnych, np. premia okresowa, podwyżka ${ }^{12}$.

\section{PODNOSZENIE EFEKTYWNOŚCI I MOTYWOWANIE ZESPOŁU}

Zespół projektowy powołany jest do życia z założeniem, że zamierzone cele będą lepiej zrealizowane $w$ grupie projektowej, niż gdyby miało to miejsce w innych warunkach, np. w sytuacji indywidualnych działań pracowników firmy. Ta przesłanka połączona jest ze skutkiem synergii, tj. z przekonaniem uzyskania lepszych rezultatów w grupie.

W procesie selekcji i rekrutacji pracowników do zespołu bardzo ważne jest kierowanie się dokładnością i postawionymi założeniami. Warto korzystać z dostępnych badań, np. testów behawioralnych, w celu lepszej weryfikacji kandydatów na członków zespołu projektowego. Największe znaczenie odgrywają umiejętności interpersonalne lidera.

Lider organizując pracę grupy, stara się uzyskać od nich maksymalną użyteczność. Innymi słowy, dąży do efektywnej, wydajnej realizacji zadań pracowników. Podnoszenie skuteczności zespołu należy do zadań trudnych, ale realnych. Jednym z bodźców efektywnej pracy jest zbudowanie więzi, ducha zespołu, jedności. Rolą lidera jest poznanie swoich podwładnych, dostosowanie zadań do ich możliwości i zaakcentowanie swojej akceptacji i szacunku dla każdej osoby w zespole. Lider jest świadomy, że wysoki poziom komunikacji w grupie jest skutecznym motywatorem do wydajnej pracy.

Nie bez znaczenia w podnoszeniu efektywności ma wielkość zespołu. Najlepsze wyniki zespół uzyskuje w małych grupach projektowych, liczących nie więcej

12 W. Bańka, Zarządzanie personelem - teoria i praktyka, Wydawnictwo Adam Marszałek, Toruń 2002, s. 59-60. 
niż 12 członków. Taka liczba pozwala na otwartą dyskusję, lepszą kontrolę zadań i wykorzystywanie wszystkich talentów w zespole. Przy zbyt dużej liczbie członków występują trudności z dopasowaniem zadań, spójności, wzajemnej kontroli i odpowiedzialności jako niezbędne katalizatory wysokiej efektywności.

Kolejnym bodźcem podnoszącym efektywność zespołu jest świadomość celów. Ukierunkowanie na konkretne cele i ich systematyczne realizowanie powoduje zadowolenie i satysfakcję ze strony pracowników. Wyobrażanie celów jest nie tylko skutecznym motywatorem do pracy, ale też płaszczyzną dla nowych rozwiązań, pomysłów.

Efektywność zespołu zależy od stylu zarządzania zespołem. Najlepszym modelem kierowania jest styl integratywny, który charakteryzuje się koncentracją współpracowników wokół omawianego zagadnienia. Lider głównie skupia się na rezultacie końcowym, na jego optymalizacji. Jednocześnie dba o swoich pracowników, o klimat i atmosferę w zespole. Okazuje sympatię podwładnym i docenia ich pracę. Jest ich przywódcą, ale też mentorem, trenerem, partnerem. Lider ufa swojej grupie, jest stanowczy, ale i wyrozumiały. Zależy mu na bezpieczeństwu i warunkach pracy. Styl ten jest nowoczesny, ale z uwagi na niepohamowane dążenie liderów do podkreślenia swojej dominacji jest relatywnie rzadko stosowany ${ }^{13}$.

Zespół projektowy ma tę właściwość, że jest unikatowy i nowatorski, przez co niezbędne staje się posiadanie pracowników o odpowiednich kompetencjach. Lider potrzebuje zespołu profesjonalistów. To z kolei rodzi nieodzowność ich doskonalenia, ciągłego podnoszenia kwalifikacji, szkoleń, kursów itp. Podnoszenie kompetencji pracowników jest jednym z najlepszych determinantów efektywnego działania. Pracownik ma poczucie rozwoju, szlifuje swoje umiejętności i twórcze myślenie. Lider ma do dyspozycji szereg narzędzi szkoleniowych.

Jednym z nich jest coaching, tj. interaktywny proces szkolenia. Najlepsze efekty osiąga się w ramach coachingu zespołowego, tzw. team coaching, który integruje grupę, orientuje na osiąganie wspólnych celów, wykształca postawę otwartości, szacunku i zrozumienia. Podnosi efektywność jednostki i grupy, buduje więź, poczucie współodpowiedzialności.

Zespół projektowy powinien zostać zbudowany w oparciu i bezpieczeństwo psychologiczne. Pracownik, który ma świadomość, że w razie kłopotów, ewentualnych błędów nie zostanie wyrzucony z pracy jest zachęcony do wydajnej pracy. Równowaga psychologiczna daje zespołowi świadomość bycia potrzebnym, ułatwia podejmowanie trudnych decyzji.

Motywowanie zespołu do efektywnej pracy wymaga zastosowania szeregu motywatorów. Projekt rządzi się swoimi prawami. Umieszczony jest w określonych ramach czasowych, wobec czego symulatory motywacyjne należy zastosować możliwie szybko. W zespole powołanym do osiągnięcia ogólnego celu, jakim jest sukces pro-

13 W. Bańka, Zarządzanie personelem..., s. 175-177. 
jektu szczególnie ważny staje się klimat organizacji. Potwierdzają to badania brytyjskiego naukowca.

Meredith Belbin zbadał systemy motywacyjne w amerykańskich przedsiębiorstwach. W niektórych obserwowanych firmach funkcjonowały systemy płacowe, które pobudzały do działania zarówno indywidualnego pracownika, jak i ogólną, zespołową wydajność. Pracownicy firmy Applebee' s zaakceptowali determinowanie części premii od zmiany atmosfery w zespole i transformacji kultury organizacji. Został wdrożony w życie system o nazwie „Big Apple Metrics”, który akcentował zmianę zachowania i postaw członków zespołu. Grupa zgodziła się na otrzymanie 5\% premii uzależnionej od stworzenia lepszego klimatu i reformowania stylu kierowania zespołem (lidera grupy). Efektem takiego systemu motywacyjnego był ogromny wzrost wyników uzyskiwanych przez firmę. Zyski zdecydowanie wzrosły i przedsiębiorstwo zajmowało czołowe miejsca na rynku w Stanach Zjednoczonych. Korelacja między atmosferą w zespole, a skutecznością organizacji była wyjątkowo wysoka. Członkowie programu byli bardzo usatysfakcjonowali wynikami i zaznaczali, jak ogromne spełnienie daje indywidualny i zbiorowy rozwój całego zespołu. Efektywny lider powinien mieć to na uwadze i starać się doskonalić pracowników i budować dobry klimat w organizacji ${ }^{14}$.

\section{PODSUMOWANIE}

Niniejsze opracowanie prezentuje zbiór najważniejszych mechanizmów, które kształtują rolę lidera w efektywnym zarządzaniu zespołem projektowym. Praca była osadzona w duchu kapitału ludzkiego, który w przypadku zespołu projektowego powinien być ciągle doskonalony. Dysponowanie kapitałem ludzkim to cenna umiejętność. Lider potrzebuje grupy profesjonalistów ukierunkowanej na sukces. Zdecydowanych pracowników, którzy wiedzą, czego chcą i nie boją się przyznać do błędu. Projekt ma duże szanse powodzenia, jeśli będzie prowadzony w duchu jedności, zrozumienia i akceptacji. Budowanie więzi zespołu nie kształtuje się w sposób naturalny. Zależy w dużej mierze od roli lidera i jego przygotowania merytorycznego i praktycznego do kierowania zespołem.

Lider musi włożyć wiele pracy i wysiłku, aby zespół wydajnie pracował, i w konsekwencji projekt zakończył się sukcesem. Zwrócenie uwagi na role zespołowe i ich właściwa alokacja w zespole pobudza innowacyjność i kreatywność, co z kolei zwiększa efekty pracy. Jak pokazały badania, firmy, który zmieniły swój klimat organizacyjny i atmosferę w miejscu pracy znacznie poprawiły swoją efektywność. Osiągnęły sukces.

14 R. Wageman, A. Debra, A. Nunes, J.A. Burruss, Zarządzanie zespołami liderów, Oficyna a Wolters Kluwer business, Warszawa 2010, s. 150-151. 
Dobry lider to taki, który zna, docenia i szanuje współpracowników. Motywuje ich do owocnej pracy i okazuje wsparcie w momentach kryzysowych. Ma wszelkie predyspozycje do efektywnego zarządzania zespołem projektowym. Lider posiada umiejętności specjalistyczne, jak: wiedza i zdobyte kwalifikacje, zdolności innowacyjne, kreatywność, analityczne myślenie. Jednak największe znaczenie odgrywają umiejętności interpersonalne, które wiążą się z kształtowaniem zespołu projektowego. Lider, który posiada wszelkie kwalifikacje do zarządzania projektem, ale nie potrafi komunikować się z grupą nie osiągnie sukcesu. Zespół projektowy to specyficzna grupa ludzi, która potrzebuje przewodnika, w postaci kierownika, który ukierunkuje ich na osiągnięcie założonych celów. Najlepszą motywację pracowników do pracy osiąga się poprzez zbudowanie dobrego klimatu organizacji. Miła atmosfera w zespole, połączona z wzajemną akceptacją i doskonałą komunikacją, przynosi sukces. Najłatwiej to wyzwanie osiągnąć właśnie w małym zespole projektowym. Im większa liczba osób w grupie, tym wzrasta stopień trudności lidera w zarządzaniu zespołem. Efektywne zarządzanie zespołem nie jest ewenementem, jednak zdolność takiego gospodarowania ludźmi, by projekt przyniósł sukces to już prawdziwe osiągnięcie.

\section{BIBLIOGRAFIA}

Bańka W., Zarządzanie personelem - teoria i praktyka, Wydawnictwo Adam Marszałek, Toruń 2002.

Belbin M., Zespoły zarządzające. Sekrety ich sukcesów i porażek, Oficyna a Wolters Kluwer business, Kraków 2009.

Bohdziewicz P. (red.), Efektywność gospodarowania kapitałem Iudzkim, Wydawnictwo Uniwersytetu Łódzkiego, Łódź 2011.

Covey R.S., Zasady skutecznego przywództwa, Dom Wydawniczy REBIS, Poznań 2004.

Kożusznik B., Kierowanie zespołem pracowniczym, Polskie Wydawnictwo Ekonomiczne, Warszawa 2005.

Wageman R., Debra A., Nunes A., Burruss J.A., Hackman R.J., Zarządzanie zespołami liderów, Oficyna a Wolters Kluwer business, Warszawa 2010.

Winkler R., Przywództwo i komunikacja w zespole projektowym, „Zeszyty Naukowe Uniwersytetu Szczecińskiego" 2013.

\section{Źródła internetowe}

www.mfiles.pl/pl/index.php/Inicjowanie_Projektu

www.mfiles.pl/pl/index.php/Zesp\%C3\%B3\%C5\%82_projektowy

www.zarzadzanieprojekt.pl 